Bond University

Research Repository

\title{
Early Signs of Impaired Gut Function Affect Daily Functioning in Patients With Advanced Cancer Undergoing Chemotherapy
}

\author{
Van der Meij, Barbara S; Deutz, Nicolaas E P; Rodriguez, Ramon E.; Engelen, Marielle P. \\ Published in: \\ Journal of Parenteral and Enteral Nutrition
}

DOI:

10.1002/jpen.1941

Licence:

Other

Link to output in Bond University research repository.

Recommended citation(APA):

Van der Meij, B. S., Deutz, N. E. P., Rodriguez, R. E., \& Engelen, M. P. (2021). Early Signs of Impaired Gut Function Affect Daily Functioning in Patients With Advanced Cancer Undergoing Chemotherapy. Journal of Parenteral and Enteral Nutrition, 45(4), 752-760. https://doi.org/10.1002/jpen.1941

\section{General rights}

Copyright and moral rights for the publications made accessible in the public portal are retained by the authors and/or other copyright owners and it is a condition of accessing publications that users recognise and abide by the legal requirements associated with these rights.

For more information, or if you believe that this document breaches copyright, please contact the Bond University research repository coordinator. 
Early signs of impaired gut function affect daily functioning in patients with advanced cancer undergoing chemotherapy

\section{Barbara S. van der Mei, PhD}

- $\quad$ Center for Translational Research in Aging \& Longevity.' Dept. Health and

Kinesiology, Texas A\&M University, College Station, TX, USA

- $\quad$ Bond University Nutrition and Dietetics Research Group, Faculty of Health Sciences and Medicine, Bond University, Australia

- Department of Dietetics and Foodservices, Mater Group, Mater Hospital, Australia

- Mater Research Institute, University of Queensland, Brisbane, Queensland, Australia

Nicolaas E.P. Deutz, PhD, MD

Center for Translational Research in Aging \& Longevity.' Dept. Health and Kinesiology, Texas A\&M University, College Station, TX, USA

Ramon E. Rodriguez, MD

Div. Hematology/Oncology, Baylor Scott and White Medical Center, College Station, TX, USA

\section{Mariëlle P.K.J. Engelen, PhD}

Center for Translational Research in Aging \& Longevity.' Dept. Health and Kinesiology, Texas A\&M University, College Station, TX, USA 


\section{Address correspondence to:}

MPKJ Engelen, PhD, Center for Translational Research in Aging \& Longevity. Dept. of Health and Kinesiology, Texas A\&M University, 675 John Kimbrough Blvd, College Station, TX 77843-4253. E-mail: mpkj.engelen@ctral.org

\section{Running title:}

Impaired gut function during chemotherapy

\section{Authorship statement:}

NEP Deutz and MPKJ Engelen equally contributed to the conception and design of the research; BS van der Meij contributed to the design of the research; BS van der Meij and RE Rodriguez contributed to the acquisition and analysis of the data; BS van der Meij, NEP Deutz and MPKJ Engelen contributed to the interpretation of the data; and BS van der Meij, NEP Deutz, RE Rodriguez and MPKJ Engelen drafted the manuscript. All authors critically revised the manuscript, agree to be fully accountable for ensuring the integrity and accuracy of the work, and read and approved the final manuscript.

Financial disclosure(s) statement:

None declared

\section{Conflicts of interest statement:}

None declared 


\section{Relevancy statement:}

This clinical study reports novel data on gut function in patients with cancer, in relation to muscle health, daily function and anabolic response to feeding. As limited research on these aspects has been published, this manuscript is of interest to doctors and nutrition experts working in oncology.

\section{Word counts:}

Abstract:

Manuscript body: 3463

\section{Acknowledgements}

This study was supported by a European Society for Clinical Nutrition and Metabolism (ESPEN) Research Fellowship in 2013. 


\section{ABSTRACT}

Aims: Gastrointestinal symptoms are common during chemotherapy, but underlying disturbances in gut function and impact on daily life are unclear. This study investigates gut function in a heterogenous group of cancer patients with gastrointestinal symptoms during chemotherapy, and the relation with anabolic response, muscle health, and daily functioning.

Methods: In 16 patients with solid tumors (mostly stage III+IV) undergoing chemotherapy $(T)$ and 16 healthy matched controls $(H)$, small intestinal membrane integrity was measured by urine sugar tests. Protein digestion, absorption and anabolic response to a conventional protein supplement were analyzed by stable tracer methods. Muscle mass and strength and daily functioning were assessed.

\section{Results:}

Eighty-one percent of T reported gastrointestinal symptoms. Small intestinal membrane permeability was similar, but active glucose transport lower in T (T: $35.5 \pm 3.4 \%$ vs. H: $48.4 \pm$ 4.7\%, $\mathrm{P}=0.03)$. Protein digestion and absorption tended to be lower in $\mathrm{T}(0.67 \pm 0.02$ vs. 0.80 $\pm 0.04, \mathrm{P}=0.08$ ). Net protein anabolic response to feeding was comparable, although lower in cancer patients with recent weight loss. Gut permeability negatively correlated to handgrip strength, global health and physical functioning and active transport capacity positively correlated to global health in $\mathrm{T}$.

\section{Conclusions:}

Advanced cancer patients with gastrointestinal symptoms during chemotherapy, particularly those with recent weight loss, show signs of impaired gut function, negatively affecting muscle health, daily functioning, and anabolic response to feeding.

$<$ PE-FRONTEND $>$ 


\section{INTRODUCTION}

Chemotherapy is one of the most common treatments for advanced cancer. Although chemotherapy can prolong life and improve treatment outcomes, it has many side effects. As the mucous membranes of the gut have a high cellular turnover, chemotherapy damages the mucosa, which often leads to symptoms such as vomiting, diarrhea and alimentary toxicity (mucositis) $(1,2)$. Gut toxicity following chemotherapy causes significant morbidity and mortality (1). For instance, diarrhea is reported in 10 to $40 \%$ of patients receiving chemotherapy $(1,3)$. It is a major chemotherapy dose-limiting factor (1) and associated with a reduced quality of life (3). Mucositis, defined as "a complication of some cancer therapies (e.g. chemotherapy) in which the lining of the digestive system becomes inflamed" (4), increases the risk of mortality, bleeding, infection, prolonged antibiotic use, longer length of hospital stay and poorer quality of life (QoL) (5). Mucositis happens in $20-40 \%$ of the patients undergoing conventional chemotherapy and in $80 \%$ of patients receiving high chemotherapy doses $(6,7)$. These studies indicate that many cancer patients, independent of cancer type, are affected by gastrointestinal symptoms during chemotherapy. However, the mechanisms behind the chemotherapy induced gut symptoms remain underexplored.

Chemotherapy causes a disruption of the microbiome (8), leading to acute gut inflammation and gastro-intestinal mucositis (7). Chemotherapy-induced diarrhea is thought to be the consequence of a multifactorial process involving gut motility, decreased transit time and elevations in gut inflammation, alterations in the gut microflora and transient lactose intolerance (1). Based on research in inflammatory bowel disorders, mucosal barrier dysfunction and tight junction defects were proposed to contribute to chemo-induced diarrhea development through leak-flux mechanisms (1). In cancer, several preclinical and clinical studies have investigated mucosal barrier function after administration of cytotoxic agents, and consistently found increased intestinal permeability, with some speculating on tight junction involvement (1). 
As a consequence of chemo-induced gut toxicity, the digestion of nutrients can be impaired in patients undergoing chemotherapy, which may cause muscle wasting and physical impairment. It has been shown that weight loss in cancer patients cannot fully be explained by reduced dietary intake and persists even when protein and energy intakes have normalized (9). Evidence exists that advanced cancer patients are characterized by anabolic resistance to a complete (protein) meal (10) despite a preserved anabolic response to dietary free essential amino acids (11). This suggests an impaired digestion and absorption capacity.

We recently developed a comprehensive panel of methods to measure gut function in disease states. We showed that the labeled phenylalanine and spirulina test (12), measuring the combined action of intraluminal, and after absorption the intracellular, breakdown of the spirulina protein and peptides, provides a good overall measure of protein digestion and absorption of a protein meal. The anabolic response to a meal can be assessed by stable isotope methodology $(13,14)$ and subsequently be adjusted for potential disturbances in protein digestion and absorption. In addition, small intestinal integrity (membrane permeability and active glucose transport), and enterocyte mass and function can be assessed by sugar tests $(5,15)$.

This study investigates whether gut function, using a panel of methods, is impaired in a heterogenous group of advanced cancer patients with gastrointestinal symptoms during chemotherapy and whether it affects muscle health, daily functioning, and anabolic response to feeding.

\section{MATERIALS AND METHODS}

\section{Subjects}

We studied 16 patients with advanced cancer and 16 gender-, age- and BMI-category matched healthy subjects from the MEDIT trial (MEtabolism of Disease with Isotope Tracers) (13). The basal protein and amino acid kinetics have been published previously (16). All subjects provided written informed consent and the study was approved by the Institutional Review Board of Texas A\&M University (reference number: 2012-0504) and registered in the Clinical Trial Registration (reference number: NCT01871350). The study took place at the 
Clinical Research Unit of the Center for Translational Research on Aging and Longevity, Texas A\&M University.

\section{General and disease characteristics}

For patients with cancer, information on tumour type, histology, stage, laboratory parameters, days since diagnosis or recurrence, days since last chemotherapy administration, chemotherapy regimen and concurrent RT was collected from medical records. Karnofsky Performance Score $(17,18)$ and unintentional weight loss in the past month was obtained. Patients completed the European Organization for Research and Treatment of Cancer (EORTC) Quality of Life Questionnaire C30 (EORTC-QLQ-C30)(19).

\section{Body composition and physical function}

Body weight and height were assessed by a digital beam scale and stadiometer, respectively and Body Mass Index was calculated (16). Total fat mass, fat-free mass (FFM), and appendicular skeletal muscle mass were measured by Dual-Energy X-ray Absorptiometry and standardized for height $\left(\mathrm{kg} / \mathrm{m}^{2}\right)(13)$. We assessed habitual dietary intake by 24-hour dietary recall (13), and physical activity using the Physical Activity Scale for the Elderly questionnaire (20).

\section{Muscle function}

Respiratory and skeletal muscle function were assessed as described before (16). Respiratory muscle tests included maximal expiratory pressure (MEP) and maximal inspiratory pressure (MIP) using a hand-held mouth pressure device (Micro Respiratory Pressure Meter (RPM) (21). Skeletal muscle function was assessed by peak leg force using Kin Com isokinetic dynamometry (Isokinetic International, Chattanooga, TN, USA) (22) and handgrip strength by Vernier dynamometry (Vernier Software and Technology, Beaverton, OR, USA) respectively (23). 


\section{Comprehensive Panel of Gut Function Measurements}

After enrollment, healthy subjects or patients with cancer returned for the 8-h study day in the postabsorptive state (Supplementary Figure 1).

\section{Small intestinal membrane integrity}

Small intestinal membrane integrity was measured by urinary recovery of orally ingested inert sugars that are not metabolized by the body. After the collection of baseline urine samples to detect natural sugar concentrations, subjects ingested $0.5 \mathrm{~g}$ L-Rhamnose (R), 7.5 g Lactulose (L) and $70 \mathrm{mg}$ 3-O-Methyl-D-Glucose (3-OMG) diluted in $70 \mathrm{~mL}$ water ( $\mathrm{t}=0 \mathrm{~h}$ ). Urine was collected over 7 hours and kept on ice, after which the total volume passed was recorded, and aliquots of $500 \mu \mathrm{l}$ were stored at $-80 \mathrm{C}$ until analysis was performed.

Lactulose is a larger non-metabolizable sugar that cannot be digested in the small intestine and only insignificant amounts are absorbed across the intestinal mucosal barrier under normal conditions. L-Rhamnose is a sugar that is passively absorbed across the intestinal mucosal barrier. 3-OMG is a larger non-metabolizable sugar with ATP-dependent absorption across the intestinal mucosal barrier. Since lactulose enters the body on a paracellular route and rhamnose by non carrier-mediated transcellular transport, urinary lactulose/rhamnose ratio is an indicator for the permeability of the small intestinal membrane and, thus, small intestinal barrier function \{Lutgens, 2005, 191-9\}. The urinary recovery of 3-OMG [\%] is an indicator for active carrier-mediated glucose transport and, thus, for intestinal absorption capacity $\{$ Lutgens, 2005, 191-9\}.

\section{$\underline{\text { Protein digestion and absorption }}$}

Protein digestion and absorption and anabolic response to a high protein meal were measured by stable tracer methods (12). We inserted a catheter into an antecubital vein for continuous stable tracer infusion and a second catheter into a superficial dorsal vein of the contralateral hand for blood sampling. The hand was placed in a thermostatically controlled 
hot box to obtain arterialized-venous blood (24). We collected baseline venous blood samples to determine the natural enrichments of PHE and TYR. From $t=2 h$ to $t=7 h$, a primed and constant, continuous stable tracer infusion containing L-[ring- $\left.{ }^{2} \mathrm{H}_{5}\right]-\mathrm{PHE}$ and L- $\left[{ }^{13} \mathrm{C}_{9},{ }^{15} \mathrm{~N}\right]-$ TYR was administered (0.177 (0.038) $\mu \mathrm{mol} / \mathrm{kg} \mathrm{FFM} / \mathrm{min}$ L-[ring- ${ }^{2} \mathrm{H}_{5}$ ]-PHE and 0.0056 (0.0012) $\left.\mu \mathrm{mol} / \mathrm{kg} \mathrm{FFM} / \mathrm{min} \mathrm{L-}\left[{ }^{13} \mathrm{C}_{9},{ }^{15} \mathrm{~N}\right]-\mathrm{TYR}\right)$. The prime contained $75 \%$ of the hourly infusion rate. At $\mathrm{t}=4 \mathrm{~h}$, participants drank a complete high protein meal within 5 to 10 minutes, the commercially available BOOST High Protein supplement $(237 \mathrm{~mL}, 15 \mathrm{~g}$ protein, $6 \mathrm{~g}$ fat, $33 \mathrm{~g}$ carbohydrates) (Société des Produits Nestlé S.A., Vevey, Switzerland), enriched with free L$\left[1-{ }^{13} \mathrm{C}\right]-\mathrm{PHE}(76.5 \mathrm{mg})$ and uniformly labeled ${ }^{15} \mathrm{~N}$-Spirulina $(1,471.15 \mathrm{mg})$ containing L- $\left[1-{ }^{15} \mathrm{~N}\right]-$ PHE. All stable tracers were purchased from Cambridge Isotope Laboratories (Woburn, MA, USA). Arterialized-venous blood was sampled 15 times from $t=2$ to $t=7.5 \mathrm{~h}$ for analysis of concentrations and tracer-tracee ratios (TTR) of amino acids, assessed by LC-MS/MS (Supplementary Figure 1).

\section{Biochemical analysis}

Arterialized-venous blood was put in Li-heparinized or EDTA tubes (Becton Dickinson Vacutainer system, Franklin Lakes, New Jersey, USA), immediately put on ice to minimize enzymatic reactions, and centrifuged $\left(4^{\circ} \mathrm{C}, 3120 \times \mathrm{g}\right.$ for $\left.5 \mathrm{~min}\right)$ to obtain plasma. A part of the plasma was aliquoted into tubes with $0.1 \mathrm{vol}$ of $33 \%(\mathrm{w} / \mathrm{w})$ trichloroacetic acid or a

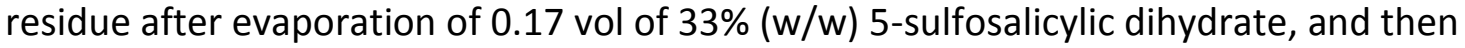
vortexed for denaturation of proteins. Samples were instantly frozen and stored at $-80^{\circ} \mathrm{C}$ until further analysis. Tracer enrichments [tracer:tracee ratio (TTR)] and plasma amino acid concentrations were analyzed by LC-MS/MS by isotope dilution as previously reported $(13,25)$. All samples were analyzed batchwise. Urine concentrations of inert sugars were obtained by LC-MS/MS and L/R and 3-OMG/R ratios were calculated as described above $(5,15,26,27)$. 


\section{Calculations of metabolic parameters}

The urinary recovery of sugars was corrected for the median of baseline (background) sugar concentrations and expressed as the percentage of oral intake. To measure small intestinal non carrier-mediated permeability and active carrier-mediated transport, respectively the lactulose/rhamnose ratio and urinary 3-OMG recovery rate [\%] was calculated.

Protein digestion and absorption were analysed by first calculating the ratio of the whole body rate of appearance of $\left[1-{ }^{15} \mathrm{~N}\right]-\mathrm{PHE}$ from ${ }^{15} \mathrm{~N}$-spirulina to the orally provided free $\left[1-{ }^{13} \mathrm{C}\right]-$ $\mathrm{PHE}$, which does not require digestion before absorption. Therefore, spirulina degradation ratio can be measured by subsequently dividing this plasma ratio by the ratio of $\left[1-{ }^{15} \mathrm{~N}\right]-\mathrm{PHE}$ to $\left[1-{ }^{13} \mathrm{C}\right]-\mathrm{PHE}$ in the protein meal (12).

We calculated protein kinetic measures (whole-body protein synthesis, breakdown, and anabolic response (=protein synthesis - breakdown)) from the isotope enrichments in the postabsorptive and postprandial state, under steady-state conditions (28-30). To correct anabolic response for protein digestion and absorption, it was not assumed that protein from the meal was completely digested, but the amount of PHE in the protein meal was multiplied by the spirulina degradation ratio. Anabolic response was in both cases corrected for splanchnic extraction. Splanchnic extraction is the fraction of orally ingested free phenylalanine that does not reach the systemic circulation because it is either not absorbed by the enterocytes or metabolized by the intestine and liver during its first pass (28-30).

\section{Statistical analysis}

Results are expressed as means \pm standard error of the mean (SEM). Population characteristics and baseline measurements were compared with the use of unpaired Student's t-tests. Alternatively, categorical values were compared with the use of the Pearson Chi-Square tests. Bivariate Pearson's correlation analysis was used to measure the linear correlation between continuous variables. The statistical package within Graphpad Prism (Version 8.0.1) and SPSS (version 26) were used for data analysis. The level of statistical significance was set at $\mathrm{P}<0.05$. 


\section{RESULTS}

We enrolled 16 patients with solid tumors undergoing chemotherapy $(T)$ and 16 age- and sex matched healthy controls $(H)$. The subjects had various types of solid tumors, mostly stage III ( $n=8,50 \%)$ and IV ( $n=7,44 \%)$, one subject had stage IIb (6\%) (Table 1). Thirty-eight percent $(n=6)$ had colorectal cancer and all but one patient received platinum-based chemotherapy. Fifty percent of patients received additional leucovorin and 5-fluorouracil (5FU). One-fourth of patients $(n=4)$ had not had any chemotherapy before enrollment; $3(19 \%)$ had undergone 1 chemotherapy cycle, and 5 patients (31\%) 2 cycles. Another one-fourth $(n=4)$ had undergone 3 or more chemotherapy cycles before enrollment. The majority $(n=15,81 \%)$ reported one or more gastrointestinal symptoms: nausea and vomiting $(n=5$, $31 \%)$, constipation $(n=7,44 \%)$, diarrhea $(n=74 \%)$ or appetite loss $(n=7,44 \%)$. Blood inflammatory markers (CRP and albumin) showed low-grade systemic inflammation.

Results on nutritional status and muscle strength have been published previously (16). Six subjects with cancer reported more than $5 \%$ weight loss in the past months (37.5\%). No significant differences were found between $\mathrm{T}$ and $\mathrm{H}$ groups in $\mathrm{BMI}$, fat-free mass index, energy and protein intake. Physical activity level assessed by the PASE questionnaire was slightly lower in cancer, however this difference was not significant (C: $135.0 \pm 25.1 \mathrm{vs.} \mathrm{H}$ : $165.1 \pm 20.7, \mathrm{P}=0.36$ ). Maximal inspiratory pressure ( $\mathrm{C}: 72.2 \pm 7.6$ vs. $\mathrm{H}: 115.8 \pm 10.5$ ) and leg extension strength (C: $252.6 \pm 29.5$ vs. $\mathrm{H}: 374.1 \pm 36.1$ ) were lower in patients with cancer $(P<0.01)(16)$.

\section{Small intestinal membrane integrity}

Average urinary $L / R$ ratios and 3-OMG/R ratios were not significantly different between groups. Urinary 3-OMG\% was lower in $\mathrm{T}(\mathrm{T}: 35.5 \pm 3.4 \%$ vs. $\mathrm{H}: 48.4 \pm 4.7 \%, \mathrm{p}=0.03$ ), indicating less capacity for active transport, as 3-OMG\% reflects ATP-dependent absorption of this sugar across the intestinal mucosal barrier (Figures 1, 2, 3). 
$L / R$ ratios in subjects with cancer correlated negatively with handgrip strength ( $r=-0.544$, $P=0.029)$, suggesting that more gut leakage is associated with poorer muscle strength.

Similarly, L/R ratios were negatively correlated with global health $(r=-0.640, P=0.008)$ and physical function ( $r=-0.550, P=0.027$ ). We found a positive correlation between $3-O M G \%$ and global health $(r=0.595, P=0.015)$, suggesting that a higher active transport capacity is associated with a better global health.

\section{Protein digestion and absorption}

Protein digestion capacity and the protein anabolic response to a meal were not significantly different between $\mathrm{T}$ and $\mathrm{H}$ (Table 3). Protein digestion capacity was not different in subjects with cancer with a lower Karnofsky Performance Score ( $\leq 70)$, higher stage of cancer (IV vs. II and III), concurrent radiotherapy, $\geq 5 \%$ weight loss, 1 or more hospital admission in the past year. No significant correlations were found between protein digestion capacity and days since recurrence, energy intake, protein intake, fat-free mass index or physical activity score (PASE).

The Spirulina-[U-15N] degradation ratio (marker of protein digestion capacity), tended to be lower in cancer subjects ( $0.67 \pm 0.02$ vs. $0.80 \pm 0.04, P=0.08)$, and was positively correlated to muscle mass index $(r: 0.532, P=0.034)$ and appendicular skeletal muscle mass ( $r: 0.532$, $\mathrm{P}=0.034)$. The uncorrected net anabolic response to the meal was higher in cancer subjects (82.2 \pm 5.1 vs. $66.65 .2 \mu \mathrm{mol} / \mathrm{kg} \mathrm{ffm} / 3 \mathrm{~h}, \mathrm{P}=0.04)$, but comparable between cancer and healthy subjects after correction for protein digestion capacity. The anabolic response corrected for protein digestion capacity was lower in weight-losing patients ( $\geq 5 \%$ weight loss: $34.2 \pm 4.2$ vs. $<5 \%$ weight loss: $47.4 \pm 2.7, P=0.015)$, and tended to be lower in patients with stage IV (IV: $36.8 \pm 3.3$ vs. II and III: $46.8 \pm 3.7, \mathrm{P}=0.064$ ), as was splanchnic extraction (IV: $-0.107 \pm 0.031$ vs. II and III: $0.043 \pm 0.053, P=0.04$ ).

Splanchnic extraction of phenylalanine was comparable between cancer and healthy subjects (Table 3). However, splanchnic extraction was negatively correlated to appendicular skeletal muscle index $(r:-0.522, P=0.038)$, and leg flexion strength $(r:-0.502$ 
$\mathrm{P}=0.048)$, indicating that a higher splanchnic extraction is associated with lower muscle mass and muscle strength.

\section{DISCUSSION}

This study investigated impairments in gut function and protein anabolic response to feeding in patients with solid tumors experiencing gastrointestinal symptoms during chemotherapy. Using a comprehensive panel of methods, we found early signs of a leaky gut and a trend towards impaired protein digestion and absorption in patients with cancer as compared to age- and gender matched healthy controls. Although small intestinal dysfunction did not reduce the protein anabolic response to feeding in cancer, intestinal dysfunction in these advanced cancer patients undergoing chemotherapy was associated with impaired muscle health and reduced daily functioning (as reflected by lower hand and leg muscle strength and self-reported global health, physical function and physical activity).

\section{Small Intestinal Barrier Function and Active Carrier-Mediated Transport}

In the current study, the lactulose/rhamnose ratio, as marker of passive transport, in patients with cancer was not different from the studied healthy controls, but higher than published normal values. However, urinary 3-OMG recovery rate was decreased in patients with cancer, suggesting a malfunction of the active carrier-mediated transport in enterocytes. L/R ratios in subjects with cancer correlated negatively with handgrip strength, global health and physical function, suggesting that more gut leakage, the lower grip strength and reported quality of life. Our findings are not completely in line with the small number of studies that have investigated gut permeability in the past. Wardill et al summarized 6 human studies documenting increased lactulose/rhamnose ratios in patients with cancer on various chemotherapy drugs (1). One of the explanations of the different findings could be the chemotherapy agents that were used in these studies, e.g. cyclophosphamide and melphalan, agents known for causing significant gut toxicity (31). In the present study, none of these agents were used in the cancer group. 
An increased small and large intestinal permeability and a reduced active carrier-mediated transport have also been reported in chronic heart failure and COPD patients (32-34). An increased intestinal permeability might result in bacterial translocation and endotoxin release causing an inflammatory immune activation (33). Although the cancer patients were characterized by low-grade systemic inflammation (average CRP: $8.6 \mathrm{mg} / \mathrm{L}$ ), we were unable to find a relationship between CRP levels and small intestinal permeability or other gut function parameters. In addition, certain co-medications might negatively affect gut integrity (34), for instance steroids that are administered in conjunction with chemotherapy.

\section{Protein Digestion and Absorption}

Protein digestion and absorption were investigated by a novel dual-tracer method and tended to be lower in the cancer group. Although the anabolic response to a meal on group level was not different between the cancer and control subjects, lower values were found in those patients who had recently lost more than $5 \%$ of their body weight and in those with stage IV disease. In these subgroups, splanchnic extraction of dietary amino acids was also elevated. In other words, weight-losing patients and those with metastatic disease had a lower anabolic response to food, at least in part related to the higher first pass extraction of amino acids by the splanchnic area, resulting in lower amino acid availability in the systemic circulation for muscle build-up. In line, splanchnic extraction was negatively correlated to muscle mass, muscle strength and physical activity. To our knowledge, this confirms that gut dysfunction plays an important role in the explanation of the observed weight loss and impaired muscle health and physical functioning in cancer patients undergoing chemotherapy. Although protein intake was similar between patients with cancer and healthy controls, reaching around $1.06 \mathrm{~g} / \mathrm{kg} / \mathrm{d}$ protein, this level of protein intake is probably not sufficient to maintain muscle mass, also taking into account gut impairments. Easy digestible (hydrolyzed) proteins with high levels of essential amino acids are important for this patient population with high protein requirements and signs of gut impairment.

A limitation of the study is the inability to differentiate the effects from cancer and chemotherapy on gut function in the human clinical setting, as both factors are taking place at the same time. It was not feasible to examine these subjects also prior to chemotherapy 
due to the short time period between diagnosis and the start of chemotherapy. In order to unravel the individual and combined effects of chemotherapy and cancer on gut function, animal research is required. Moreover, due to the heterogeneity of the patient population with regard to tumour type, chemotherapy regime, and the duration that patients had received chemotherapy, our data need to be interpreted with caution. However, we showed that in this mixed group of cancer patients with solid tumors and different chemotherapy treatments, nearly all patients experienced gastrointestinal symptoms and a relatively homogenous gut function profile was observed.

In conclusion, patients with advanced cancer and gastrointestinal symptoms during chemotherapy show early signs of a leaky gut and impaired digestion, which is associated with impaired muscle health and some markers of daily functioning. Future research is required to explore interventions that can compensate for the increased maldigestion and splanchnic extraction, in order to maintain muscle mass, muscle strength, and physical function during chemotherapy.

\section{REFERENCES}

1. Wardill HR, Bowen JM. Chemotherapy-induced mucosal barrier dysfunction: An updated review on the role of intestinal tight junctions. Current Opinion in Supportive and Palliative Care. 2013.

2. Andreyev J, Ross P, Donnellan C, Lennan E, Leonard P, Waters C, et al. Guidance on the management of diarrhoea during cancer chemotherapy. The Lancet Oncology. 2014.

3. Keefe DM, Elting LS, Nguyen HT, Grunberg SM, Aprile G, Bonaventura A, et al. Risk and outcomes of chemotherapy-induced diarrhea (CID) among patients with colorectal cancer receiving multi-cycle chemotherapy. Cancer Chemother Pharmacol. 2014;

4. National Cancer Institute - mucositis [Internet]. [cited 2002 Feb 11]. Available from: https://www.cancer.gov/publications/dictionaries/cancer-terms/def/mucositis

5. Blijlevens NMA, Donnelly JP, de Pauw BE. Prospective evaluation of gut mucosal barrier injury following various myeloablative regimens for haematopoietic stem cell transplant. Bone Marrow Transplant. 2005; 
6. Touchefeu Y, Montassier E, Nieman K, Gastinne T, Potel G, Bruley Des Varannes S, et al. Systematic review: The role of the gut microbiota in chemotherapy- or radiation-induced gastrointestinal mucositis - Current evidence and potential clinical applications. Alimentary Pharmacology and Therapeutics. 2014.

7. Jones MP, Dilley JB, Drossman D, Crowell MD. Brain-gut connections in functional GI disorders: Anatomic and physiologic relationships. Neurogastroenterol Motil. 2006;18(2):91-103.

8. Bindels LB, Thissen JP. Nutrition in cancer patients with cachexia: A role for the gut microbiota? Clin Nutr Exp. 2016;

9. Hung Y-C, Bauer J, Horsley P, Waterhouse M, Bashford J, Isenring E. Changes in nutritional status, body composition, quality of life, and physical activity levels of cancer patients undergoing autologous peripheral blood stem cell transplantation. Support Care Cancer [Internet]. 2013 Jun [cited 2016 Oct 10];21(6):1579-86. Available from:

http://www.ncbi.nlm.nih.gov/pubmed/23306934

10. Antoun S, Raynard B. Muscle protein anabolism in advanced cancer patients: Response to protein and amino acids support, and to physical activity. Ann Oncol. 2018;

11. Engelen MPKJ, Safar AM, Bartter T, Koeman F, Deutz NEP. High anabolic potential of essential amino acid mixtures in advanced nonsmall cell lung cancer. Ann Oncol Off J Eur Soc Med Oncol [Internet]. 2015 Sep [cited 2017 Nov 26];26(9):1960-6. Available from: https://academic.oup.com/annonc/article-lookup/doi/10.1093/annonc/mdv271

12. Engelen MPKJ, Com G, Anderson PJ, Deutz NEP. New stable isotope method to measure protein digestibility and response to pancreatic enzyme intake in cystic fibrosis. Clin Nutr [Internet]. 2014 Dec [cited 2016 Feb 3];33(6):1024-32. Available from: http://www.pubmedcentral.nih.gov/articlerender.fcgi?artid=4306434\&tool=pmcentrez\&ren dertype=abstract

13. Deutz NEP, Thaden JJ, ten Have GAM, Walker DK, Engelen MPKJ. Metabolic phenotyping using kinetic measurements in young and older healthy adults. Metabolism [Internet]. 2018 Jan 3 [cited 2017 Nov 26];78:167-78. Available from: 
http://www.ncbi.nlm.nih.gov/pubmed/28986165

14. Kim IY, Deutz NEP, Wolfe RR. Update on maximal anabolic response to dietary protein. Clinical Nutrition. 2018.

15. Nieuwenhoven MA, Swart EA, Eijk HM, Deutz NE, Brouns F, Brummer RJ. Effects of pre- and post-absorptive factors on the lactulose/rhamnose gut permeability test. Clinical.science. 2000;

16. Van Der Meij BS, Deutz N, Rodriguez R, Engelen M. Increased amino acid turnover and myofibrillar protein breakdown in advanced cancer are associated with muscle weakness and impaired physical function. Clin Nutr. 2018;

17. Karnofsky D, Burchenal J. The clinical evaluation of chemotherapeutic agents in cancer. In: In: Evaluation of chemotherapeutic agents MacLeod CM, editor New York: Columbia University Press; 1949 The clinical evaluation of chemotherapeutic agents in cancer; [Internet]. 1948. p. 191-205. Available from:

http://www.ncbi.nlm.nih.gov/pubmed/19403886

18. Yates JW, Chalmer B, McKegney FP. Evaluation of patients with advanced cancer using the Karnofsky performance status. Cancer [Internet]. 1980 Apr 15 [cited 2017 May 11];45(8):2220-4. Available from: http://www.ncbi.nlm.nih.gov/pubmed/7370963

19. Aaronson NK, Ahmedzai S, Bergman B, Bullinger M, Cull A, Duez NJ, et al. The European Organization for Research and Treatment of Cancer QLQ-C30: a quality-of-life instrument for use in international clinical trials in oncology. J Natl Cancer Inst [Internet]. 1993 Mar 3 [cited 2017 May 11];85(5):365-76. Available from:

http://www.ncbi.nlm.nih.gov/pubmed/8433390

20. Washburn RA, Montoye HJ. The assessment of physical activity by questionnaire. Am J Epidemiol [Internet]. 1986 Apr [cited 2017 May 10];123(4):563-76. Available from: http://www.ncbi.nlm.nih.gov/pubmed/3513548

21. Vernieri C, Casola S, Foiani M, Pietrantonio F, de Braud F, Longo V. Targeting cancer metabolism: dietary and pharmacological interventions. Cancer Discov. 2016;6(12):13151333. 
22. Saey $D$, Debigaré $R$, LeBlanc $P$, Jeffery Mador $M$, Côté $C H$, Jobin J, et al. Contractile leg fatigue after cycle exercise: A factor limiting exercise in patients with chronic obstructive pulmonary disease. Am J Respir Crit Care Med. 2003;168(4):425-30.

23. Bohannon RW, Magasi SR, Bubela DJ, Wang Y-C, Gershon RC. Grip and Knee extension muscle strength reflect a common construct among adults. Muscle Nerve [Internet]. 2012 Oct [cited 2017 Nov 26];46(4):555-8. Available from:

http://www.ncbi.nlm.nih.gov/pubmed/22987697

24. Abumrad NN, Rabin D, Diamond MP, Lacy WW. Use of a heated superficial hand vein as an alternative site for the measurement of amino acid concentrations and for the study of glucose and alanine kinetics in man. Metabolism [Internet]. 1981 Sep [cited 2017 May 9];30(9):936-40. Available from: http://www.ncbi.nIm.nih.gov/pubmed/7022111

25. Engelen MPKJ, Safar AM, Bartter T, Koeman F, Deutz NEP. Reduced arginine availability and nitric oxide synthesis in cancer is related to impaired endogenous arginine synthesis. Clin Sci (Lond). 2016;

26. Lim SG, Menzies IS, Lee CA, Johnson MA, Pounder RE. Intestinal permeability and function in patients infected with human immunodeficiency virus: A comparison with coeliac disease. Scand J Gastroenterol. 1993;28(7):573-80.

27. Parviainen I, Takala J, Jakob SM. Does fluid loading influence measurements of intestinal permeability? Crit Care. 2005;

28. Jonker R, Deutz NEP, Harrykissoon R, Zachria AJ, Veley EA, Engelen MPKJ. A critical evaluation of the anabolic response after bolus or continuous feeding in COPD and healthy older adults. Clin Sci. 2018;

29. Jonker R, Deutz NEP, Schols AMWJ, Veley EA, Harrykissoon R, Zachria AJ, et al. Whole body protein anabolism in COPD patients and healthy older adults is not enhanced by adding either carbohydrates or leucine to a serving of protein. Clin Nutr. 2019;

30. Jonker R, Deutz NEP, Ligthart-Melis GC, Zachria AJ, Veley EA, Harrykissoon R, et al. Preserved anabolic threshold and capacity as estimated by a novel stable tracer approach suggests no anabolic resistance or increased requirements in weight stable COPD patients. 
Clin Nutr. 2019;

31. eviQ [Internet]. New South Wales Government. 2019. Available from:

https://www.eviq.org.au/search?searchtext=cyclophosphamide

32. Sandek A, Swidsinski A, Schroedl W, Watson A, Valentova M, Herrmann R, et al. Intestinal blood flow in patients with chronic heart failure: A link with bacterial growth, gastrointestinal symptoms, and cachexia. J Am Coll Cardiol. 2014;

33. Sandek A, Bjarnason I, Volk HD, Crane R, Meddings JB, Niebauer J, et al. Studies on bacterial endotoxin and intestinal absorption function in patients with chronic heart failure. Int J Cardiol. 2012;

34. König J, Wells J, Cani P, García-Ródenas C, MacDonald T, Mercenier A, et al. Human Intestinal Barrier Function in Health and Disease. Clin Transl Gastroenterol. 2016;7(10). 
Table 1. Characterization of the individual patients with cancer

Table 2. Whole body prandial protein metabolism after intake of a high-energy, high protein meal in healthy controls and cancer patients

Figure 1. L/R ratios in healthy controls and cancer patients

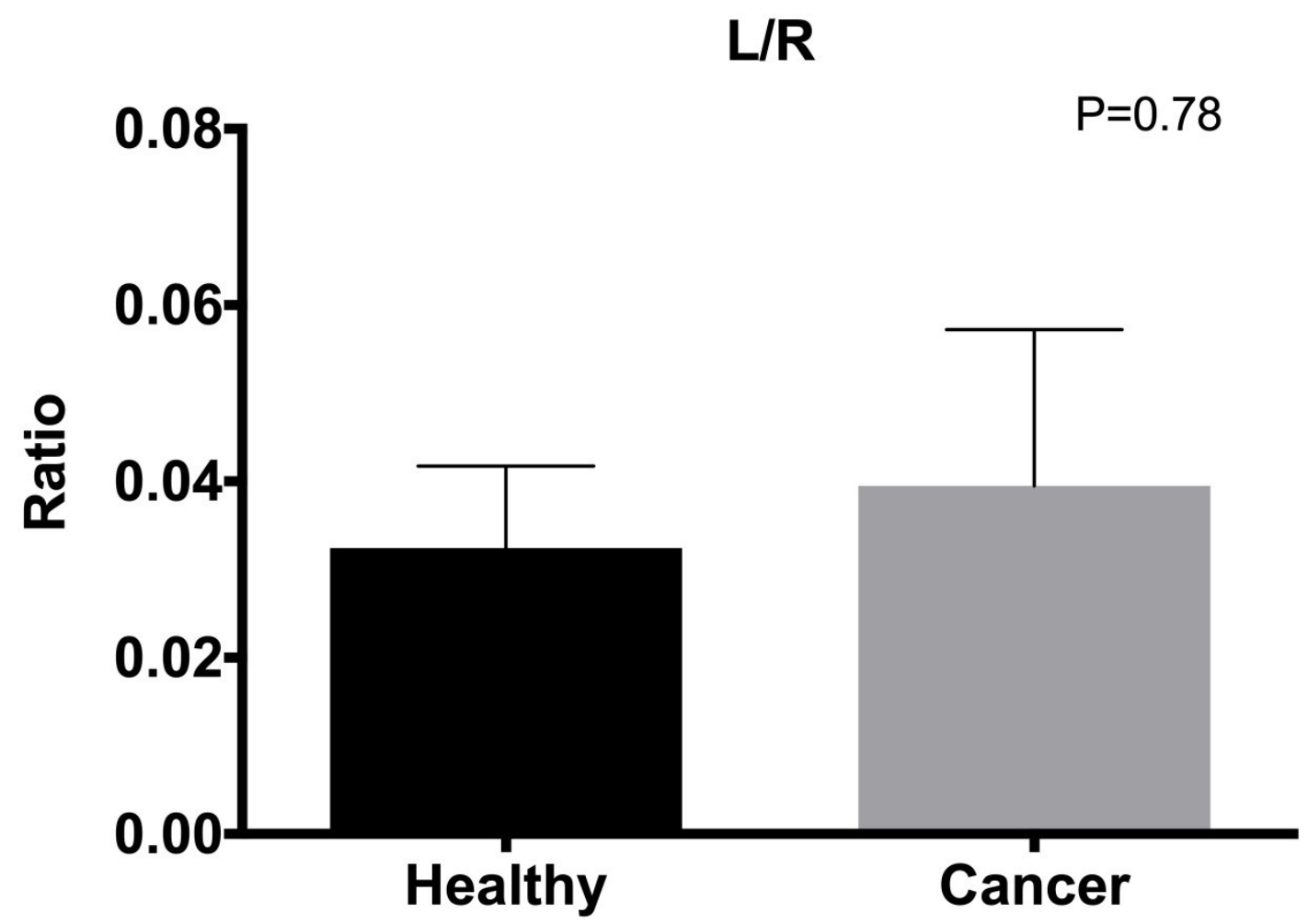


Figure 2. 3-OMG/R ratios in healthy controls and cancer patients

\section{3-OMG/R}

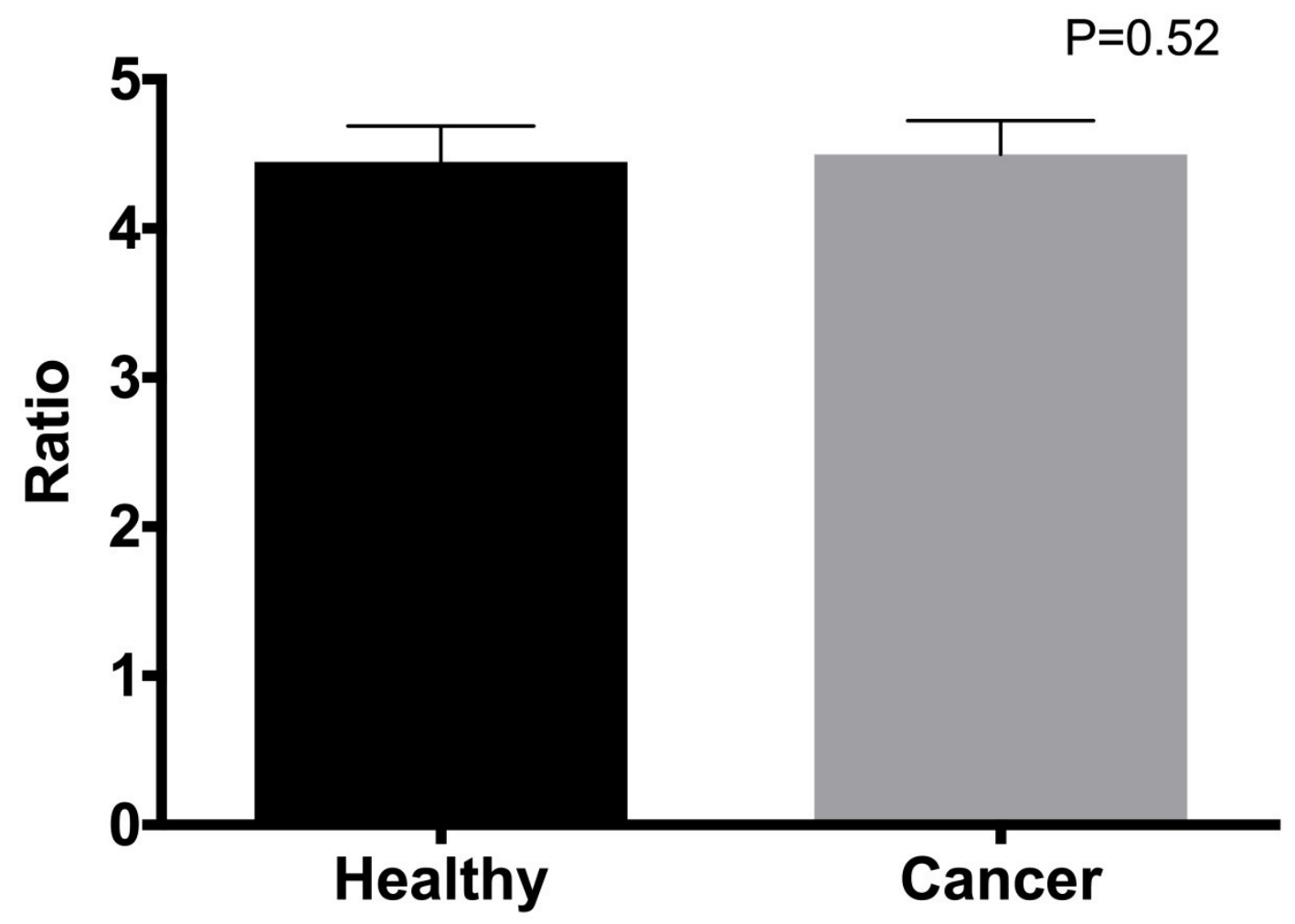


Figure 3. 3-OMG (\%) in healthy controls and cancer patients

\section{3-OMG}

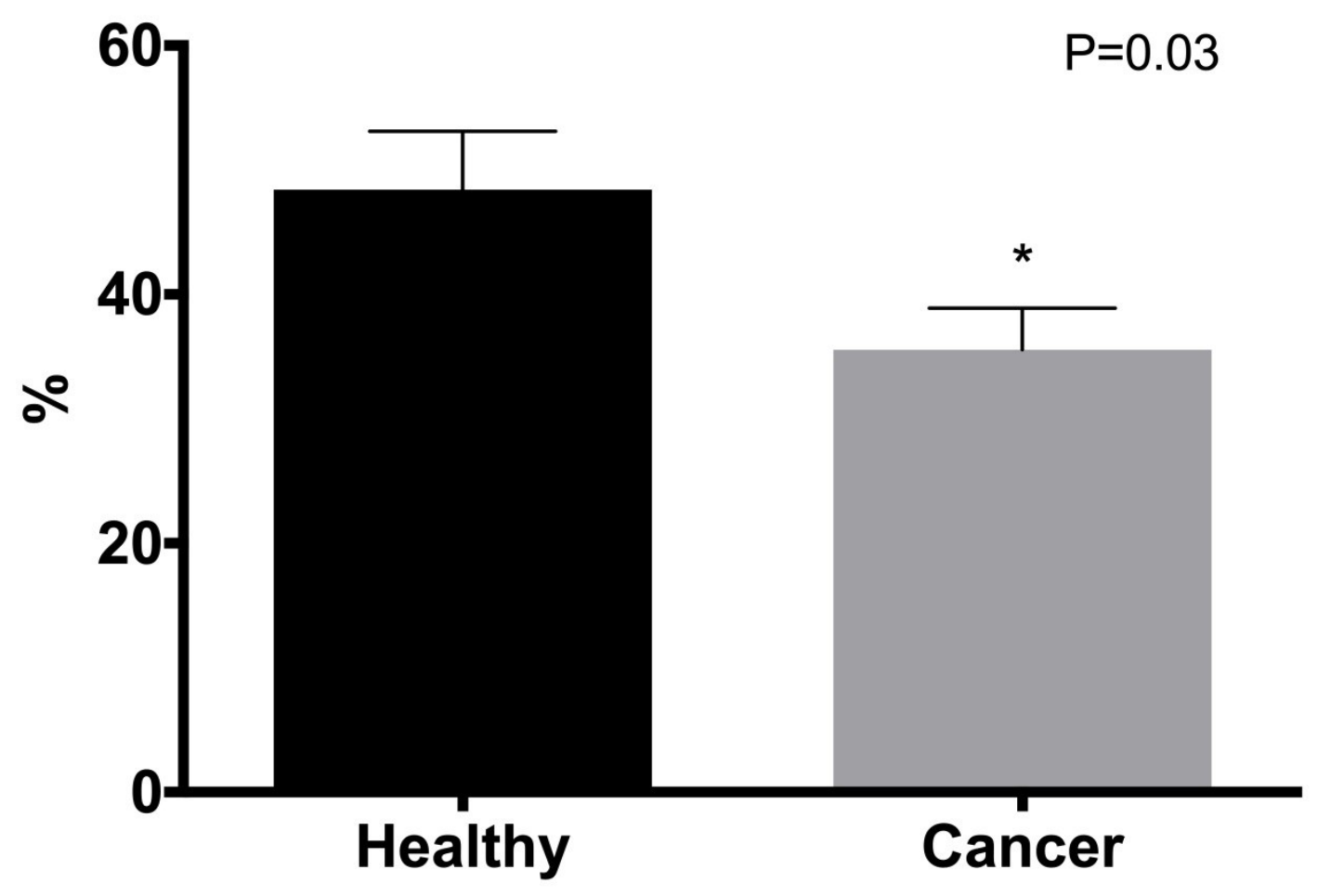


Table 1. Characterization of the individual patients with cancer

\begin{tabular}{|c|c|c|c|c|c|c|c|c|c|c|c|c|}
\hline $\begin{array}{l}\text { I } \\
\text { D }\end{array}$ & $\begin{array}{l}\mathrm{S} \\
\mathrm{e} \\
\mathrm{x}\end{array}$ & $\begin{array}{l}\text { A } \\
\text { ge }\end{array}$ & Histology & $\begin{array}{l}\text { Sta } \\
\text { ge }\end{array}$ & $\begin{array}{c}\text { Seru } \\
\text { m } \\
\text { CRP } \\
\text { (mg/ } \\
\text { L) / } \\
\text { Albu } \\
\text { min } \\
\text { (g/dL } \\
\text { ) }\end{array}$ & $\begin{array}{c}\text { Rad } \\
\text { ia- } \\
\text { tion } \\
\text { (Y/ } \\
\mathrm{N})\end{array}$ & $\begin{array}{l}\text { Chemo- } \\
\text { therapy } \\
\text { drugs / } \\
\text { frequen } \\
\text { cy }\end{array}$ & $\begin{array}{l}\text { Cycle } \\
\text { s } \\
\text { recei } \\
\text { ved } \\
\text { befor } \\
\text { e } \\
\text { test } \\
\text { day } \\
\text { (n) }\end{array}$ & $\begin{array}{l}\text { Time } \\
\text { diagn } \\
\text { osis - } \\
\text { test } \\
\text { day } \\
\text { (d) }\end{array}$ & $\begin{array}{l}\text { Time last } \\
\text { chemoth } \\
\text { erapy - } \\
\text { test day } \\
\text { (d) }\end{array}$ & $\begin{array}{c}\text { Glob } \\
\text { al } \\
\text { Healt } \\
\text { h / } \\
\text { Physi } \\
\text { cal } \\
\text { Funct } \\
\text { ion } \\
\text { (scor } \\
\text { e) }\end{array}$ & $\begin{array}{c}\text { Appetit } \\
\text { e loss / } \\
\text { Diarrho } \\
\text { ea / } \\
\text { Constip } \\
\text { ation / } \\
\text { Nausea- } \\
\text { Vomitin } \\
\text { g (\% of } \\
\text { subjects } \\
\text { ) }\end{array}$ \\
\hline 1 & $M$ & 72 & $\begin{array}{c}\text { Gastric - } \\
\text { Adeno }\end{array}$ & IV & $5.9 /$ & $\mathrm{N}$ & $\begin{array}{c}\text { Cisplatin } \\
\text {, 5-FU, } \\
\text { LV } \\
\text { / } 2 \mathrm{wks} \\
\text { on, } 1 \mathrm{wk} \\
\text { off }\end{array}$ & 0 & 35 & -2 & $\begin{array}{l}92 / \\
100\end{array}$ & $\begin{array}{c}0 / 0 / 0 \\
/ 0\end{array}$ \\
\hline 2 & $M$ & 66 & $\begin{array}{c}\text { Esophag } \\
\text { eal - } \\
\text { Adeno }\end{array}$ & IV & 14.4 & $N$ & $\begin{array}{c}\text { Carbopl } \\
\text { atin, } \\
\text { paclitax } \\
\text { el, } \\
\text { docetax } \\
\text { el, 5-FU, } \\
\text { LV } \\
\text { / } \\
\text { weekly }\end{array}$ & 0 & 19 & -1 & $\begin{array}{l}42 / \\
100\end{array}$ & $\begin{array}{c}33 / 0 / \\
0 / 0\end{array}$ \\
\hline 3 & $M$ & 66 & $\begin{array}{l}\text { Pancreati } \\
\text { c-Adeno }\end{array}$ & III & 0.5 & $Y$ & $\begin{array}{c}\text { Oxalipla } \\
\text { tin, } \\
\text { irinotec } \\
\text { an, 5- } \\
\text { FU, LV } \\
\text { / } \\
\text { fortnigh }\end{array}$ & 0 & 10 & -4 & $\begin{array}{c}33 / \\
87\end{array}$ & $\begin{array}{l}67 / 0 / \\
33 / 17\end{array}$ \\
\hline
\end{tabular}




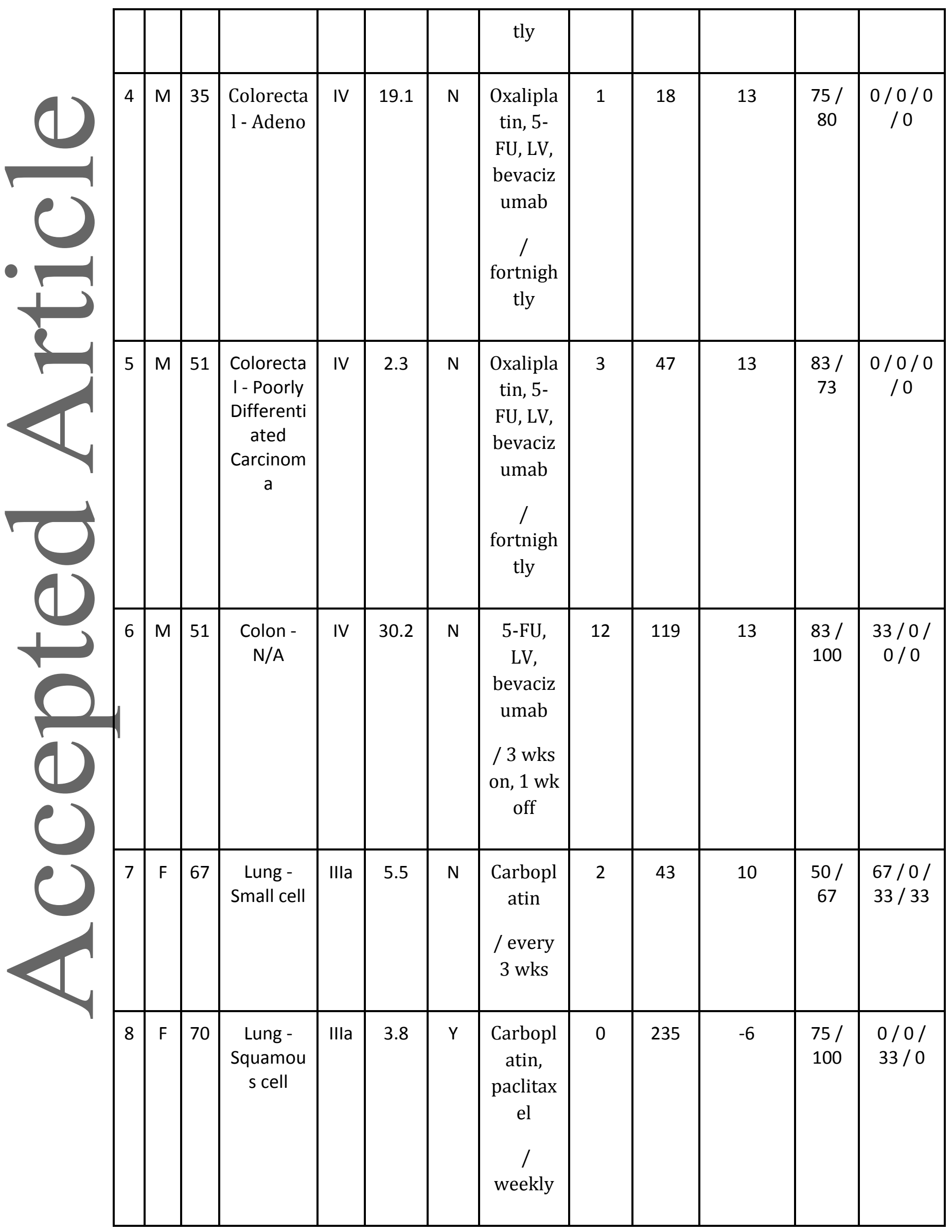




\begin{tabular}{|c|c|c|c|c|c|c|c|c|c|c|c|c|}
\hline 9 & $M$ & 62 & $\begin{array}{l}\text { Rectal - } \\
\text { Adeno }\end{array}$ & III & 0.2 & $Y$ & $\begin{array}{l}\text { Oxalipla } \\
\text { tin, 5- } \\
\text { FU, LV } \\
\text { / } \\
\text { fortnigh } \\
\text { tly }\end{array}$ & 1 & 205 & 8 & $\begin{array}{c}75 / \\
80\end{array}$ & $\begin{array}{c}0 / 33 / \\
67 / 0\end{array}$ \\
\hline $\begin{array}{l}1 \\
0\end{array}$ & $M$ & 74 & $\begin{array}{l}\text { Colon - } \\
\text { Adeno }\end{array}$ & IIIb & 2.3 & $\mathrm{~N}$ & $\begin{array}{c}\text { Oxalipla } \\
\text { tin, 5- } \\
\text { FU, LV } \\
\text { / } \\
\text { fortnigh } \\
\text { tly }\end{array}$ & 2 & 63 & 10 & $\begin{array}{c}75 / \\
93\end{array}$ & $\begin{array}{c}0 / 33 / \\
67 / 0\end{array}$ \\
\hline $\begin{array}{l}1 \\
1\end{array}$ & $\mathrm{~F}$ & 63 & $\begin{array}{l}\text { Colon - } \\
\text { Adeno }\end{array}$ & IV & 1.1 & $\mathrm{~N}$ & $\begin{array}{c}\text { Carbopl } \\
\text { atin, } \\
\text { paclitax } \\
\text { el } \\
\text { / } \\
\text { fortnigh } \\
\text { tly }\end{array}$ & 2 & 77 & 9 & $\begin{array}{c}25 / \\
53\end{array}$ & $\begin{array}{c}0 / 33 / \\
0 / 17\end{array}$ \\
\hline $\begin{array}{l}1 \\
2\end{array}$ & $M$ & 76 & $\begin{array}{l}\text { Esophage } \\
\text { al - } \\
\text { Squamou } \\
\text { s cell, } \\
\text { poorly } \\
\text { differenti } \\
\text { ated }\end{array}$ & IV & 4.0 & $Y$ & $\begin{array}{c}\text { Carbopl } \\
\text { atin, } \\
\text { paclitax } \\
\text { el } \\
\text { / } 2 \\
\text { weeks } \\
\text { on, } 1 \mathrm{wk} \\
\text { of }\end{array}$ & 2 & 43 & 5 & $\begin{array}{c}58.3 \\
/ \\
86.9\end{array}$ & $\begin{array}{c}100 / \\
33.3 / 0 \\
/ 16.7\end{array}$ \\
\hline $\begin{array}{l}1 \\
3\end{array}$ & $\mathrm{~F}$ & 86 & $\begin{array}{l}\text { Ovarian - } \\
\text { unknown }\end{array}$ & III & 6.8 & $\mathrm{~N}$ & $\begin{array}{c}\text { Carbopl } \\
\text { atin, } \\
\text { paclitax } \\
\text { el } \\
\text { / } \\
\text { weekly }\end{array}$ & 2 & 71 & 3 & $\begin{array}{c}33.3 \\
/ \\
46.7\end{array}$ & $\begin{array}{c}0 / 66.7 \\
/ 33.3 / \\
0\end{array}$ \\
\hline $\begin{array}{l}1 \\
4\end{array}$ & $F$ & 40 & $\begin{array}{l}\text { Lung - } \\
\text { Adeno }\end{array}$ & IIIb & 5.6 & $Y$ & $\begin{array}{c}\text { Carbopl } \\
\text { atin, }\end{array}$ & 5 & 74 & 6 & $\begin{array}{l}83.3 \\
/ 100\end{array}$ & $\begin{array}{c}100 / \\
33.3 / 0\end{array}$ \\
\hline
\end{tabular}




\begin{tabular}{|c|c|c|c|c|c|c|c|c|c|c|c|c|}
\hline & & & & & & & $\begin{array}{c}\text { paclitax } \\
\text { el } \\
\text { / } \\
\text { weekly }\end{array}$ & & & & & 10 \\
\hline $\begin{array}{l}1 \\
5\end{array}$ & $F$ & 22 & $\begin{array}{c}\text { Ovarian - } \\
\text { Adeno }\end{array}$ & III & 28.3 & $\mathrm{~N}$ & $\begin{array}{c}\text { Carbopl } \\
\text { atin, } \\
\text { paclitax } \\
\text { el } \\
\text { / } \\
\text { weekly }\end{array}$ & 5 & 83 & 5 & $\begin{array}{c}58.3 \\
/ \\
80.0\end{array}$ & $\begin{array}{c}0 / 33.3 \\
/ 0 / 0\end{array}$ \\
\hline $\begin{array}{l}1 \\
6\end{array}$ & $F$ & 60 & $\begin{array}{c}\text { Ovarian/ } \\
\text { Uterus }\end{array}$ & IIb & 13.2 & $\mathrm{~N}$ & $\begin{array}{c}\text { Carbopl } \\
\text { atin, } \\
\text { docetax } \\
\text { el } \\
\text { / every } \\
3 \text { wks }\end{array}$ & 1 & 63 & 16 & $\begin{array}{c}50.0 \\
/ \\
86.7\end{array}$ & $\begin{array}{c}66.7 / 0 \\
/ 33.3 / \\
16.7\end{array}$ \\
\hline
\end{tabular}

M: male, F: female, Y: yes, N: no, 5-FU: fluorouracil, LV: leucovorin. Global health and Physical function were assessed by EORTC-QLQ-C30 questionnaire 
Table 2. Whole body prandial protein metabolism after intake of a high-energy, high protein meal in healthy controls and cancer patients

\begin{tabular}{|c|c|c|c|}
\hline Mean (SEM) & $\begin{array}{l}\text { Healthy } \\
\text { controls } \\
(n=16)\end{array}$ & $\begin{array}{l}\text { Cancer } \\
\text { patients } \\
(n=16)\end{array}$ & $\begin{array}{l}\text { P-value } \\
\text { Healthy vs. } \\
\text { Cancer }\end{array}$ \\
\hline $\begin{array}{l}\text { Protein synthesis ( } \mu \mathrm{mol} / \mathrm{kg} \mathrm{ffm} / 3 \mathrm{~h}) \\
\text { ffpheps }\end{array}$ & $330.4(13.1)$ & $359.0(9.8)$ & 0.09 \\
\hline $\begin{array}{l}\text { Endogenous protein synthesis, corrected for } \\
15 \mathrm{~N} \text {-spirulina }(\mu \mathrm{mol} / \mathrm{kg} \mathrm{ffm} / 3 \mathrm{~h}) \\
\text { ffpheendo }\end{array}$ & $263.8(10.9)$ & 276.8 (9.9) & 0.39 \\
\hline $\begin{array}{l}\text { Net protein synthesis }(\mu \mathrm{mol} / \mathrm{kg} \mathrm{ffm} / 3 \mathrm{~h}) \text {, } \\
\text { uncorrected } \\
\text { ffphenetps }\end{array}$ & $66.6(5.2)$ & $82.2(5.1)$ & 0.04 \\
\hline $\begin{array}{l}\text { Net protein synthesis, corrected for } 15 \mathrm{~N} \text { - } \\
\text { spirulina }(\mu \mathrm{mol} / \mathrm{kg} \mathrm{ffm} / 3 \mathrm{~h}) \\
\text { ffphenetpsspir }\end{array}$ & $47.1(6.0)$ & $42.4(2.8)$ & 0.49 \\
\hline $\begin{array}{l}\text { 15N-Spirulina degradation (ratio) } \\
\text { ff15nspir }\end{array}$ & $0.80(0.04)$ & $0.67(0.02)$ & 0.08 \\
\hline $\begin{array}{l}\text { Splanchnic extraction (ratio) } \\
\text { fspephe }\end{array}$ & $\begin{array}{c}0.024 \\
(0.025)\end{array}$ & $\begin{array}{l}-0.023 \\
(0.037)\end{array}$ & 0.31 \\
\hline
\end{tabular}


